\title{
Effects of the Dietary Supplementation of Sucupira (Pterodon Emarginatus Vog.) and Copaiba (Copaifera Langsdorffii) Resinoils on Chicken Breast and Thigh Meat Quality and Oxidative Stability
}

mAuthor(s)

\author{
Lima CB del \\ Racanicci AMC \\ Oliveira GR' \\ Migotto DL \\ Amador SA' \\ Souza TC del \\ Tanure CBGS"I \\ Vieira $A^{\mathrm{IV}}$
}

Graduate students, Faculty of Agriculture and Veterinary, University of Brasília (UnB)

" Professor and supervisor, Faculty of Agriculture and Veterinary, University of Brasília (UnB)

II' Post-Doctor, Faculty of Agriculture and Veterinary, University of Brasília (UnB)

Iv Professor, Department of Statistics, University of Brasília (UnB)

\section{-Mail Address}

Corresponding author e-mail address Aline Mondini Calil Racanicci

Faculdade de Agronomia e Medicina Veterinária (FAV) - Universidade de Brasília

(UnB), Campus Darcy Ribeiro, ICC Ala Sul,

CEP 70.910-970, Brasília/DF.

Phone: (61) 3107-7157

E-mail: alinemcr@unb.br

\section{EKeywords}

Antioxidant, Brazilian plants, broiler meat, meat quality, TBARS.

\section{ABSTRACT}

An experiment was conducted to evaluate the addition of the oil resins of sucupira (Pterodon emarginatus Vog.) and copaiba (Copaifera langsdorffii) to broiler diets on chicken meat composition, quality, and lipid peroxidation. 350 one-d-old broiler chicks were submitted to seven treatments, consisting of the diets supplemented with copaiba (COP) or sucupira (SUC) resin oils at three different concentrations $(500,900$, and $1300 \mathrm{ppm}$ ) plus a negative control diet (CONT). At 37 days of age, 10 birds per treatment were selected according to the average weight of the experimental unit and slaughtered to collect breast and thigh meat, which was stored at $4^{\circ} \mathrm{C}$ for 24 hours to evaluate $\mathrm{pH}$, color $\left(L^{*}, a^{*}, b^{*}\right)$, cooking weight loss $(C W L)$, and shear force (SF). Raw meat was vacuum packed and stored frozen until lipid peroxidation analysis. Meat samples were pooled to prepare pre-cooked meatballs (30 $\pm 0.5 \mathrm{~g}$ ), stored under refrigeration (eight days), and analyzed every two days for TBARS concentration. Results were analyzed using the PROC GLM and MIXED procedures (SAS statistical software). Plant oils increased $(p<0.05)$ breast meat humidity $(H U)$ and crude protein $(C P)$ levels and reduced $(p<0.05)$ total lipid $(T L C)$ and ash $(A S)$ levels when compared with the CONT treatment. Plant oils increased $(p<0.05)$ thigh meat $\mathrm{HU}$ when compared with the CONT. High COP dietary levels reduced $(p<0.05)$ breast meat $C W L$, and increased $(p<0.05)$ thigh meat $L^{*}$ values when compared to CONT, except for SUC500 and SUC900. The dietary inclusion of plant oil resins showed a pro-oxidant effect $(p<0.01)$ on breast meat when compared with the CONT. Low SUC dietary supplementation levels significantly reduced $(p<0.01)$ the concentration of secondary oxidation products in thigh meat.

\section{INTRODUCTION}

Oxidation is a natural process of cell metabolism that leads to the formation of free radicals. It normally occurs in the cytoplasm, primarily inside the mitochondria as a result of phosphorylation (Cardenas \& Davies, 2000). However, when it occurs in a disorganized manner, it triggers a chain reaction with the uncontrolled formation of free radicals, which will negatively affect proteins, DNA, carbohydrates, pigments, vitamins and particularly lipids, and originate toxic volatile and non-volatile components (Min \& Ahn, 2005; Lynch \& Faustman, 2000; Kanner, 1994).

The susceptibility of meat to lipid peroxidation depends on several factors, such as animal species, muscle type and anatomical location. For instance, broiler meat is more sensitive to oxidation than red meat because it has a higher polyunsaturated fatty acid content. Also, chicken thigh meat has a higher lipid content, and therefore, it is more prone to oxidation compared with breast meat (Melton, 1983; Cortinas et al., 2004). 
Lima CB de, Racanicci AMC, Oliveira GR, Migotto DL, Amador SA, Souza TC de, Tanure CBGS, Vieira A
Effects of the Dietary Supplementation of Sucupira (Pterodon Emarginatus Vog.) and Copaiba (Copaifera Langsdorffii) Resinoils on Chicken Breast and Thigh Meat Quality and Oxidative Stability
The process of meat lipid peroxidation probably starts immediately after slaughter. The biochemical changes that occur during the conversion of muscle into meat associated with the content of polyunsaturated fatty acid and the processing operations applied in the industry such as grounding, cooking and the addition of salt, promote meat oxidation, resulting in progressive degradation. This oxidative stress causes an imbalance between pro-oxidant and antioxidant meat contents, accelerating meat degradation (Morrisey et al., 1998; Araújoet al., 2007; Gandemer, 2002).

Meat lipid peroxidation negatively affects meat nutrient content and leads to the production of volatile and non-volatile toxic substances, such as aldehydes, ketones, and alcohols, which are compounds that cause off-color, off-flavor (rancidity, warmed-over flavor), and off-odor changes, reducing the shelf life of meat and meat products (Gayatán et al., 2010).

Therefore, in an attempt to prevent meat degradation, antioxidant compounds may be supplemented in animal diets. Natural antioxidants are an alternative to the use of synthetic compounds, which have restricted use since reports indicate they pose risks to human health, such as hepatotoxicity and cancer (EU, 2012). Natural antioxidants derived from plants, especially those from the Brazilian Cerrado biome, have high antioxidant potential (Anand \& Sati, 2013; Passoto et al., 1998).

The dietary supplementation of plant extracts is an efficient means to prevent meat peroxidation, because natural antioxidants are metabolized by the body and subsequently incorporated directly into the muscle. In addition, several research papers report an additional increase of $\alpha$-tocopherol levels in the muscle of many animal species as a consequence of natural antioxidant dietary supplementation (Kim et al., 2006; Smet et al., 2008; Liu et al, 2010; Haak et al., 2008).

The plants sucupira (Pterodon emarginatus Vog.) and copaiba (Copaifera langsdorffii) are commonly found in the Cerrado biome. The oil resin extracted from both plants is composed of isoflavones, sesquiterpenes and diterpenes, which are phenolic compounds with high antioxidant capacity, specially their main component B-caryophyilene (Dutra et al., 2008; Herrero-Jáuregui et al., 2011).

Therefore, the objective of this study was to evaluate the antioxidant capacity of sucupira and copaiba oil resins supplemented in broiler diets on lipid peroxidation and on chicken breast and thigh meat quality.

\section{MATERIAL AND METHODS}

\section{Sucupira and copaiba oil resins}

The copaiba oil resin was mechanically extracted directly from the woody portion of the trees, while sucupira oil was produced by cold pressing of the seeds, obtaining $15 \%$ crude oil yield. Both oil resins were obtained in collaboration with a regional cooperative of sustainable production in Central Region of Brazil.

Oil resins were analyzed to determine their purity and then were standardized at the Natural Products Research Laboratory (Pharmacy Department, Federal University of Goiás, UFG), located in Goiânia, Brazil. Copaiba and sucupira oil resins contained $21.31 \%$ and $7.36 \% \beta$-caryophyllene, respectively.

\section{Birds and diets}

The experimental procedures were approved by the Ethics Committee of UFG under protocol n. 030/2012 UFG/CEUA.

The experiment was conducted according to a completely randomized experimental design in $2 \times 3$ factorial arrangement (2 plants: SUC and COP; 3 dietary addition levels: 500, 900 and 1300 ppm), and a negative control treatment, totaling seven treatments, with five replicates of 10 birds each.

In total, 350 one-d-old male Cobb500 ${ }^{\circledR}$ broilers were housed at the experimental facilities of the Veterinary Department, UFG, state of Goiás, Brazil. Birds were housed in distributed in 35 galvanized steel battery cages $(0.5 \mathrm{~m} \times 0.4 \mathrm{~m} \times 0.4 \mathrm{~m})$ at 10 birds per cage, which represented an experimental unit. Water and feed were supplied ad libitum in trough drinkers and feeders. The lighting program consisted of 23 hours of light plus one hour of darkness. For environmental control, 60W lamps were used for brooding until 14 days of age, plastic side curtains for the control of environmental temperature.

Birds were fed diets based on corn and soybean meal formulated to supply their nutritional requirements during pre-starter, starter and grower phases, according to Rostagno et al. (2011).

The dietary treatments consisted of a negative control diet (CONT, Table 1), and of the supplementation of three different sucupira and copaiba oil resin levels mixed with soybean oil and added to the CONT diet at the expense of corn starch, as follows: $500 \mathrm{mg}$ of sucupira (SUC500) or copaiba (COP500) oil resin/ $\mathrm{kg}$ of feed; $900 \mathrm{mg}$ of sucupira (SUC900) or copaiba (COP900) oil resin/kg of feed; and 1,300 mg of sucupira (SUC 1300) or copaiba (COP1300) oil resin/kg of feed. 
Lima CB de, Racanicci AMC, Oliveira GR, Migotto DL, Amador SA, Souza TC de, Tanure CBGS, Vieira A
Effects of the Dietary Supplementation of Sucupira (Pterodon Emarginatus Vog.) and Copaiba (Copaifera Langsdorffii) Resinoils on Chicken Breast and Thigh Meat Quality and Oxidative Stability
Table 1 - Ingredient composition and calculated nutritional values of the basal diets, according to rearing phase.

\begin{tabular}{|c|c|c|c|}
\hline Ingredients & $\begin{array}{c}\text { Pre-starter } \\
\text { (1-7days) }\end{array}$ & $\begin{array}{c}\text { Starter } \\
\text { (8-21 days) }\end{array}$ & $\begin{array}{c}\text { Grower } \\
\text { (22-37 days) }\end{array}$ \\
\hline Ground corn & 55.29 & 59.82 & 62.05 \\
\hline Soybean meal & 38.25 & 34.67 & 31.54 \\
\hline Soybean oil & 2.05 & 1.88 & 2.99 \\
\hline Dicalcium phosphate & 1.90 & 0.99 & 1.28 \\
\hline Limestone & 0.90 & 1.24 & 0.85 \\
\hline Salt & 0.50 & 0.49 & 0.45 \\
\hline DL-Methionine 99\% & 0.36 & 0.29 & 0.26 \\
\hline L-Lysine $\mathrm{HCl}$ & 0.29 & 0.21 & 0.19 \\
\hline Corn starch & 0.20 & 0.20 & 0.20 \\
\hline L-threonine $98 \%$ & 0.11 & 0.06 & 0.04 \\
\hline Vitamin Suplement ${ }^{1}$ & 0.10 & 0.10 & 0.10 \\
\hline Mineral Suplement ${ }^{2}$ & 0.05 & 0.05 & 0.05 \\
\hline \multicolumn{4}{|l|}{ Calculated Values } \\
\hline Metabolizable energy (kcal/kg) & 2,950 & 3,000 & 3,100 \\
\hline Crude Protein (\%) & 22.20 & 20.80 & 19.50 \\
\hline Digestible Lysine (\%) & 1.31 & 1.17 & 1.07 \\
\hline Digestible Methionine+Cystine & 0.94 & 0.84 & 0.78 \\
\hline Calcium (\%) & 0.92 & 0.81 & 0.73 \\
\hline Available Phosphorus (\%) & 0.47 & 0.39 & 0.34 \\
\hline Sodium (\%) & 0.22 & 0.21 & 0.20 \\
\hline
\end{tabular}

'Supplied per kg of supplement: 3,125,000 IU Vitamin A; 550,000 IU Vitamin D3; 3,750 mg Vitamin E; 625 mg Vitamin K3; 250 mg Vitamin B1; 1,125 mg Vitamin B2; $250 \mathrm{mg}$ Vitamin B6; 3,750mg Vitamin B12; 9,500 mg niacin; 3,750 mg calcium pantothenate; $125 \mathrm{mg}$ folic acid; 350,000 mg DL-methionine; 150,000 mg choline chloride 50\%; 50 mg selenium.

${ }^{2}$ Suppliedper kg of supplement: manganese 150,000mg; zinc 100,000mg; iron 100,000mg; copper 16,000mg; iodine 1,500mg.

\section{Meat Samples}

When broilers were 37 days old, 10 birds per treatment were selected according to the average bodyweight of the pen, and transported in crates inside an open truck to a commercial processing plant (state inspection n. 0221-98) located $47 \mathrm{~km}$ from the city of Goiânia. Broilers were slaughtered under commercial conditions, according to the Brazilian legislation (Brasil, 2000).

Breast was deboned, and thighs were separated from the carcass, identified according to treatments, packed in plastic bags, and immediately transported on ice to the Animal Nutrition Laboratory (UnB), located in Brasília, DF, Brazil.

\section{Meat composition}

The chemical composition of raw samples of breast and thigh meat was determined in triplicate. Moisture, crude protein, and ash contents were analyzed according to the AOAC (1990), and total lipid content according to the AOAC (1995).

\section{Meat pH and color}

After transportation, meat samples were stored under refrigeration $\left(4^{\circ} \mathrm{C}\right)$ for 24 hours, after which the $\mathrm{pH}$ and color of each breast and thigh meat sample were evaluated in triplicate. The $\mathrm{pH}$ was recorded using a portable $\mathrm{pH}$ meter $\left(\right.$ Testo $\left.^{\circledR}\right)$, and color (CIELAB System: $\mathrm{L}^{*}=$ lightness, $\mathrm{a}^{*}=$ redness and $\mathrm{b}^{*}=$ yellowness) was measured using a Konica-Minolta colormeter (Chroma Meter (R-400).

\section{Meat tenderness}

Meat tenderness was evaluated by cooking weight loss (CWL) and shear force (SF) applied in breast meat only. Approximately one third of the right portion of Pectoralis major muscle from each bird was analyzed 24 hours post mortem. Ten samples per treatment were cut into $2.5-\mathrm{cm}$ diameter cubes. For CWL determination, samples were weighed and cooked in an electric oven, preheated to $170^{\circ} \mathrm{C}$, until $70^{\circ} \mathrm{C}$ internal temperature monitored with a Termopar thermometer (Testo ${ }^{\circledR}$ ) inserted in the center of the cube presenting the average weight of the batch. After reaching the desired internal temperature, the cubes were cooled and weighed to calculate CWL. The cubes were then packed and stored in a refrigerator overnight. Shear force was evaluated as described by Froning \& Uijttenboogaart (1988). Cylindrical samples measuring $1.27-\mathrm{cm}$ diameter were cut from the meat cubes parallel to the muscle fibers. The samples were cut perpendicular to the fiber using a Warner-Bratzler ${ }^{\circledR}$ texture analyzer with a $V$ type of blade, $1.016-\mathrm{cm}$ thickness, and fixed speed of $20 \mathrm{~cm} / \mathrm{min}$. Results were presented in percentage (\%) for CWL and in $\mathrm{kg}$-force (kgf) for SF.

\section{Meat lipid peroxidation}

The remaining samples of breast and thigh meat were vacuum packed in oxygen-impermeable bags and stored frozen until two storage trials were carried out to evaluate the progress of lipid oxidation in breast and thigh meats individually.

Defrosted breast or thigh meat samples were minced and $0.5 \%$ of food grade salt was added to produce meatballs weighing $30 \mathrm{~g}( \pm 0.5 \mathrm{~g})$. Meatballs were vacuum packed and precooked in water bath at $100^{\circ} \mathrm{C}$ for 10 minutes, according to Racanicci et al. (2004). Meatballs were repacked in oxygen-permeable bags and stored chilled at $4^{\circ} \mathrm{C}$ in the dark for eight days. Secondary lipid peroxidation products were evaluated on days $0,2,4,6$ and 8 of storage by quantification of malondialdehyde using TBARS (thiobarbituric 
Lima CB de, Racanicci AMC, Oliveira GR, Migotto DL, Amador SA, Souza TC de, Tanure CBGS, Vieira A
Effects of the Dietary Supplementation of Sucupira (Pterodon Emarginatus Vog.) and Copaiba (Copaifera Langsdorffii) Resinoils on Chicken Breast and Thigh Meat Quality and Oxidative Stability acid reactive substances). TBARS was determined in duplicate in two meatballs per treatment, according to Madsen et al. (1998). Absorbance was measured at 532 and $600 \mathrm{~nm}$, using Gehaka model UV-340G spectrophotometer. Results were expressed in $\mu$ mols of malondialdehyde (MAD) per $\mathrm{kg}$ of meat, using an 1,1,3,3-tetraethoxypropane (TEP) standard curve.

\section{Statistical Analysis}

Dietary chemical composition, CWL, and SF data were analyzed using general linear model procedure (PROC GLM); whereas color $\left(L^{*}, a^{*}, b^{*}\right), p H$, and TBARS data were analyzed using mixed procedure (PROC MIXED) of SAS $9.3\left(\right.$ SAS $\left.^{\circledR}\right)$ statistical software. In the analyses of lipid peroxidation results, storage period was considered a longitudinal factor $(0,2,4$, 6 , and 8 days) in the PROC MIXED, with fixed effects for treatments and random effects for storage period. Lipid peroxidation results were fit to a linear regression model.

\section{RESULTS AND DISCUSSION}

\section{Meat Composition}

Averages of the evaluated breast meat composition parameters are shown in Table 2 . The humidity $(\mathrm{HU})$, ash (AS), and crude protein (CP) contents obtained in this study are consistent with the $74.8 \% \mathrm{HU}, 1 \% \mathrm{AS}$, and $21.5 \%$ CP values presented in the Brazilian Table of Food Composition (NEPA, 2011). Although total lipid content (TLC) observed in the present experiment is not in agreement with the findings of Torres et al. (2000), the averages are similar to those described in the National Food Database (USDA, 2012).

The inclusion of the oil resins in the diet resulted in a significant $\mathrm{HU}$ increase $(p<0.05)$ and in a significant TLC decrease $(p<0.05)$ in the breast meat, when compared with the CONT diet. Ash content (AS) of the SUC500, COP900 and COP1300 diets were significantly lower $(p<0.05)$ than that of the CONT diet, but similar to other treatments. On the other hand, diets with the oil resins presented higher $C P$ content $(p<0.05)$ relative to the CONT diet, except for the SUC500 and SUC900 diets.

Table 3 shows the average chemical composition of thigh meat. The obtained HU and TLC average results (72.21-75.62\% HU and 4.51-6.14\% TLC) are consistent with those obtained by Novello et al. (2008), but higher than those reported by Torres et al. (2000).

In the present study, the treatment COP900 promoted the highest $\mathrm{HU}$ content $(p<0.05)$ in thigh meat when compared with other treatments, including CONT, which yielded the lowest HU value. Average $\mathrm{CP}$ contents were similar among treatments, except for COP1300, which resulted in the highest CP value $(p<0.05)$. In addition, dietary treatments did not affect TLC values, except for SUC900, which resulted in the lowest TLC value $(p<0.05)$. No differences in AS content were detected among treatments.

It is important to remember that many factors, such as genetics and nutrition, may influence the chemical composition of meat, especially CP and TLC contents (Lonergan et al., 2003; Wang et al., 2013), and may have contributed for the differences found between the results of this study and other literature reports.

\section{Meat Quality}

Breast meat quality results are described in Table 4. Averages values of $\mathrm{pH}$, luminosity $\left(L^{*}\right)$, redness $\left(a^{*}\right)$, and yellowness $\left(b^{*}\right)$ were not affected by treatments, as previously reported by Leonel et al. (2007), when evaluating the supplementation of vitamin $\mathrm{E}$ in broiler diets. Similarly, the supplementation of broilers diets with oregano (3\%) did not affect meat $\mathrm{pH}$ values, as described by Young et al. (2003). On the other hand, Simitzis et al. (2011) reported a significant ( $p>0.05$ ) meat $\mathrm{pH}$ reduction with the supplementation of hesperidin, a bioflavonoid, in broilers diets.

Table 2 - Average chemical composition (humidity, HU; ashes, AS; crude protein, CP; and total lipid content, TLC) of breast meat samples, expressed as a percentage (\%) of natural matter (NM).

\begin{tabular}{|c|c|c|c|c|}
\hline Treatment* & $\mathrm{HU}$ & AS & $C P$ & TLC \\
\hline CONT & $74.16^{f} \pm 0.01$ & $1.62^{a} \pm 0.01$ & $22.88^{c} \pm 0.03$ & $1.00^{a} \pm 0.00$ \\
\hline SUC500 & $74.66^{b} \pm 0.01$ & $1.57^{b} \pm 0.00$ & $22.86^{c} \pm 0.15$ & $0.83^{b c} \pm 0.02$ \\
\hline SUC900 & $74.71^{\mathrm{a}} \pm 0.01$ & $1.60^{\mathrm{ab}} \pm 0.00$ & $23.33^{b c} \pm 0.13$ & $0.83^{b} \pm 0.03$ \\
\hline SUC 1300 & $74.55^{c} \pm 0.01$ & $1.60^{a b} \pm 0.00$ & $23.65^{a b} \pm 0.10$ & $0.82^{b c} \pm 0.02$ \\
\hline COP500 & $74.44^{d} \pm 0.00$ & $1.59^{\mathrm{ab}} \pm 0.01$ & $23.85^{\mathrm{ab}} \pm 0.02$ & $0.81^{b c} \pm 0.03$ \\
\hline COP900 & $74.25^{e} \pm 0.02$ & $1.57^{b} \pm 0.02$ & $24.10^{\mathrm{a}} \pm 0.17$ & $0.73^{c} \pm 0.01$ \\
\hline COP1300 & $74.68^{\mathrm{ab}} \pm 0.00$ & $1.57^{b} \pm 0.01$ & $23.67^{\mathrm{ab}} \pm 0.04$ & $0.87^{b} \pm 0.01$ \\
\hline
\end{tabular}

$a, b, c$ Means with different letters in the same row are statistically different $(p<0.05)$.

* Negative control without antioxidants (CONT) or dietary supplementation of 500, 900, or 1300 ppm of sucupira (SUC) or copaiba (COP) oil resins. 
Table 3 - Average chemical composition (humidity, HU; ashes, AS; crude protein, CP; and total lipid content, TLC) of thigh meat samples, expressed as a percentage (\%) of natural matter (NM).

\begin{tabular}{lllll}
\hline Treatment* & HU & AS & CP & TLC \\
\hline CONT & $74.45^{\mathrm{e}} \pm 0.01$ & $1.48 \pm 0.00$ & $20.13^{\mathrm{b}} \pm 0.04$ & $4.77^{\mathrm{a}} \pm 0.09$ \\
SUC500 & $74.88^{\mathrm{b}} \pm 0.01$ & $1.51 \pm 0.01$ & $19.90^{\mathrm{b}} \pm 0.01$ & $4.63^{\mathrm{a}} \pm 0.12$ \\
SUC900 & $74.7^{\mathrm{cd}} \pm 0.02$ & $1.50 \pm 0.00$ & $19.88^{\mathrm{b}} \pm 0.12$ & $4.15^{\mathrm{b}} \pm 0.07$ \\
SUC1300 & $74.65^{\mathrm{d}} \pm 0.02$ & $1.48 \pm 0.01$ & $19.86^{\mathrm{b}} \pm 0.07$ & $4.66^{\mathrm{a}} \pm 0.09$ \\
COP500 & $74.88^{\mathrm{b}} \pm 0.01$ & $1.49 \pm 0.00$ & $19.50^{\mathrm{b}} \pm 0.10$ & $4.57^{\mathrm{a}} \pm 0.03$ \\
COP900 & $74.98^{\mathrm{a}} \pm 0.00$ & $1.47 \pm 0.01$ & $20.16^{\mathrm{b}} \pm 0.32$ & $4.69^{\mathrm{a}} \pm 0.10$ \\
COP1300 & $75.74^{\mathrm{c}} \pm 0.01$ & $1.50 \pm 0.01$ & $20.87^{\mathrm{a}} \pm 0.10$ & $4.60^{\mathrm{a}} \pm 0.02$ \\
\hline
\end{tabular}

$a, b, c$ Means with different letters in the same row are statistically different $(p<0.05)$.

* Negative control without antioxidants (CONT) or dietary supplementation of 500, 900, or 1300 ppm of sucupira (SUC) or copaiba (COP) oil resins.

Average lightness values $\left(L^{*}\right)$ obtained in this study (Table 4) ranged between 48 and 50, and therefore, can be considered normal, according to Qiao et al. (2001) findings (normal $=48<L^{*}>53$ ). The treatments did not influence $L^{*}, a^{*}$ and $b^{*}$ values, which are consistent with the results of Zhang et al. (2012), when evaluating the supplementation of broilers diets with different levels of $\alpha$-tocopherol acetate.

The addition of oil resins affected $(p<0.05)$ cooking weight loss of the breast meat samples, with the lowest value (11.90) obtained with the supplementation of COP900. On the other hand, the breast meat of broilers fed the SUC 1300 and COP500 diets presented higher CWL values (20.95 and 20.58) compared with those fed the CONT diet (14.51). Overall, these values are different from those reported by Almeida et al. (2002) and Castro et al. (2008), but are consistent with the results of Barbut et al. (2005), who determined11.25\% CWL in chicken breast meat classified as normal. In the present study, SF averages were not affected by treatments.

According to Aaslyng et al. (2003), there is a correlation between $\mathrm{pH}$ and $\mathrm{CWL}$, in which lower $\mathrm{pH}$ values are associated with reduced water holding capacity in poultry meat. Therefore, higher CWL values are expected when meat presents reduced $\mathrm{pH}$ values (Northcutt et al., 1994; Shafey et al., 2014). However, this correlation was not detected in breast meat in the present study (Table 3), because, although the dietary addition of SUC oil resin influenced CWL $(p<0.05)$, no meat $\mathrm{pH}$ changes were detected. This correlation may not have been detected due to the influence of other factors on meat CWL, such as cooking, mincing, and chilling (Bouton et al., 1971; Cheng \& Sun, 2008).

It is well established that CWL and SF values are related to breast meat tenderness and water holding capacity when it is submitted to heat, maintaining water inside intramuscular fibers (Müller et al., 2012). Therefore, it seems that the increase in dietary SUC oil resin levels negatively affected $(p<0.05) C W L$; on the other hand, the results suggest that the increase in dietary COP levels may improve meat tenderness.

No significant $\mathrm{pH}$ differences ( $p>0.05$ ) were detected among treatments, as shown in Table 5 . These values are consistent with the results of Mirshekar et al. (2009), who evaluated the dietary supplementation of 1,000 ppm of rosemary, echinacea, green tea extracts, and ascorbic acid on meat quality, and did not find any broiler meat $\mathrm{pH}$ differences ( $\mathrm{pH} 6.29$ to 6.37). On the other hand, the addition of copaiba oil resin (COP500,

Table 4 - Average $\mathrm{pH}$, color $\left(\mathrm{L}^{*}, \mathrm{a}^{*}, \mathrm{~b}^{*}\right)$, cooking weight loss $(\mathrm{CWL})$, shear force $(\mathrm{SF})$ values and their respective standard deviation in breast meat samples.

\begin{tabular}{|c|c|c|c|c|c|c|}
\hline \multirow[b]{2}{*}{ Treatment* } & \multirow[b]{2}{*}{$\mathrm{pH}$} & \multicolumn{3}{|c|}{ Color } & \multirow[b]{2}{*}{ CWL } & \multirow[b]{2}{*}{ SF } \\
\hline & & $L^{*}$ & $a^{*}$ & $b^{*}$ & & \\
\hline CONT & 5.95 & 48.00 & 3.19 & 6.87 & $14.51^{b c}$ & 1.76 \\
\hline SUC500 & 6.03 & 49.15 & 2.99 & 7.58 & $15.28^{b c}$ & 1.82 \\
\hline SUC900 & 6.04 & 48.05 & 3.44 & 6.99 & $17.49^{a b}$ & 2.08 \\
\hline SUC 1300 & 6.00 & 48.48 & 3.98 & 6.97 & $20.95^{a}$ & 1.93 \\
\hline COP500 & 6.01 & 49.12 & 2.38 & 5.60 & $20.58^{a}$ & 1.63 \\
\hline COP900 & 5.99 & 49.08 & 2.54 & 5.78 & $11.90^{d}$ & 1.33 \\
\hline COP1300 & 5.97 & 50.40 & 3.44 & 6.14 & $13.56^{\mathrm{cd}}$ & 1.74 \\
\hline Stand. Dev. & 0.05 & 1.25 & 0.86 & 1.02 & 1.23 & 0.66 \\
\hline
\end{tabular}


Lima CB de, Racanicci AMC, Oliveira GR, Migotto DL, Amador SA, Souza TC de, Tanure CBGS, Vieira A

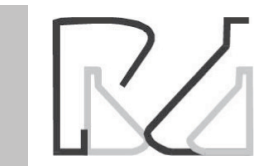

900, and 1300), as well as SUC 1300, resulted in higher $(p<0.05) L *$ averages compared with the CONT diet. In general, thigh meat $L^{*}$ average values in the present study are lower than those reported by Mirshekar et al. (2009), of 60.80 to 65.20 after 24 post mortem, but are close to those obtained by Leonel et al. (2007) when evaluating the effects of vitamin E supplementation $(300 \mathrm{mg} / \mathrm{kg})$ on chicken meat quality ( $\left.L^{*}: 46.56-48.32\right)$.

Table 5 - Average $\mathrm{pH}$, color $\left(L^{*}, a^{*}, b^{*}\right)$, cooking weight loss (CWL), shear force (SF) values and their respective standard deviation in thigh meat samples.

\begin{tabular}{lcccc}
\hline & & \multicolumn{3}{c}{ Color } \\
\cline { 3 - 5 } Treatment* & $\mathrm{pH}$ & $\mathrm{L}^{*}$ & $\mathrm{a}^{*}$ & $\mathrm{~b}^{*}$ \\
\hline CONT & 6.41 & $47.71^{\mathrm{c}}$ & 10.80 & 8.17 \\
SUC500 & 6.38 & $48.51^{\mathrm{bc}}$ & 10.47 & 8.53 \\
SUC900 & 6.50 & $48.42^{\mathrm{bc}}$ & 11.14 & 8.76 \\
SUC1300 & 6.49 & $49.09^{\mathrm{ab}}$ & 11.98 & 8.77 \\
COP500 & 6.47 & $49.85^{\mathrm{a}}$ & 12.19 & 8.23 \\
COP900 & 6.35 & $49.55^{\mathrm{a}}$ & 11.98 & 8.70 \\
COP1300 & 6.38 & $49.92^{\mathrm{a}}$ & 12.24 & 8.70 \\
\hline Stand. Dev. & 0.06 & 0.41 & 0.94 & 0.35 \\
\hline a,b,c Means with different letters in the same row are statistically different (p<0.05). & \\
* Negative control without antioxidants (CONT) or dietary supplementation of 500, \\
900, or 1300 ppm of sucupira (SUC) or copaiba (COP) oil resins.
\end{tabular}

In this study, the dietary addition of SUC and COP oil resins did not affect ( $p>0.05)$ thigh meat $a^{*}$ and $b *$ values, as previously described by Mirshekar et al. (2009); however, the redness $\left(a^{*}\right)$ values detected by latter were slightly lower (8.23 to 9.53).
Effects of the Dietary Supplementation of Sucupira (Pterodon Emarginatus Vog.) and Copaiba (Copaifera Langsdorffii) Resinoils on Chicken Breast and Thigh Meat Quality and Oxidative Stability

\section{Lipid peroxidation}

Malondialdehyde (MAD) concentration was measured in breast and thigh meatballs on days 0,2 , 4,6 , and 8 of storage under refrigeration. The results are shown in Figures 1 and 2, respectively. As expected, TBARS increased for all treatments during the storage period.

On day zero (Figure 1), the breast and thigh meat of broilers fed the COP500, COP900, and COP1300 diets presented lower $(p<0.0001)$ MAD levels when compared with those fed the CONT diet. Similar results were detected for the treatments SUC500, SUC900, and SUC 1300 in the breast meat $(p<0.0001)$. However, TBARS thigh meat values were not affected by the SUC treatments.

Figure 1 shows that the TBARS values of the breast meat balls derived from broilers fed the SUC diets increased ( $p=0.0020)$ from day 2 of storage, suggesting a pro-oxidant effect as the dietary concentration of the oil resin of this plant increased. On day8, the dietary inclusion of SUC and COP - particularly of SUC900 - significantly increased $(p=0.0912)$ TBARS levels compared with the CONT diet.

Relative to thigh meat (Figure 2), the COP1300 treatment resulted insignificantly lower $(p=0.0344)$ TBARS concentration of than the CONT treatment on day 4. On day 8, the treatments with low SUC and COP concentrations (SUC500 and COP500)

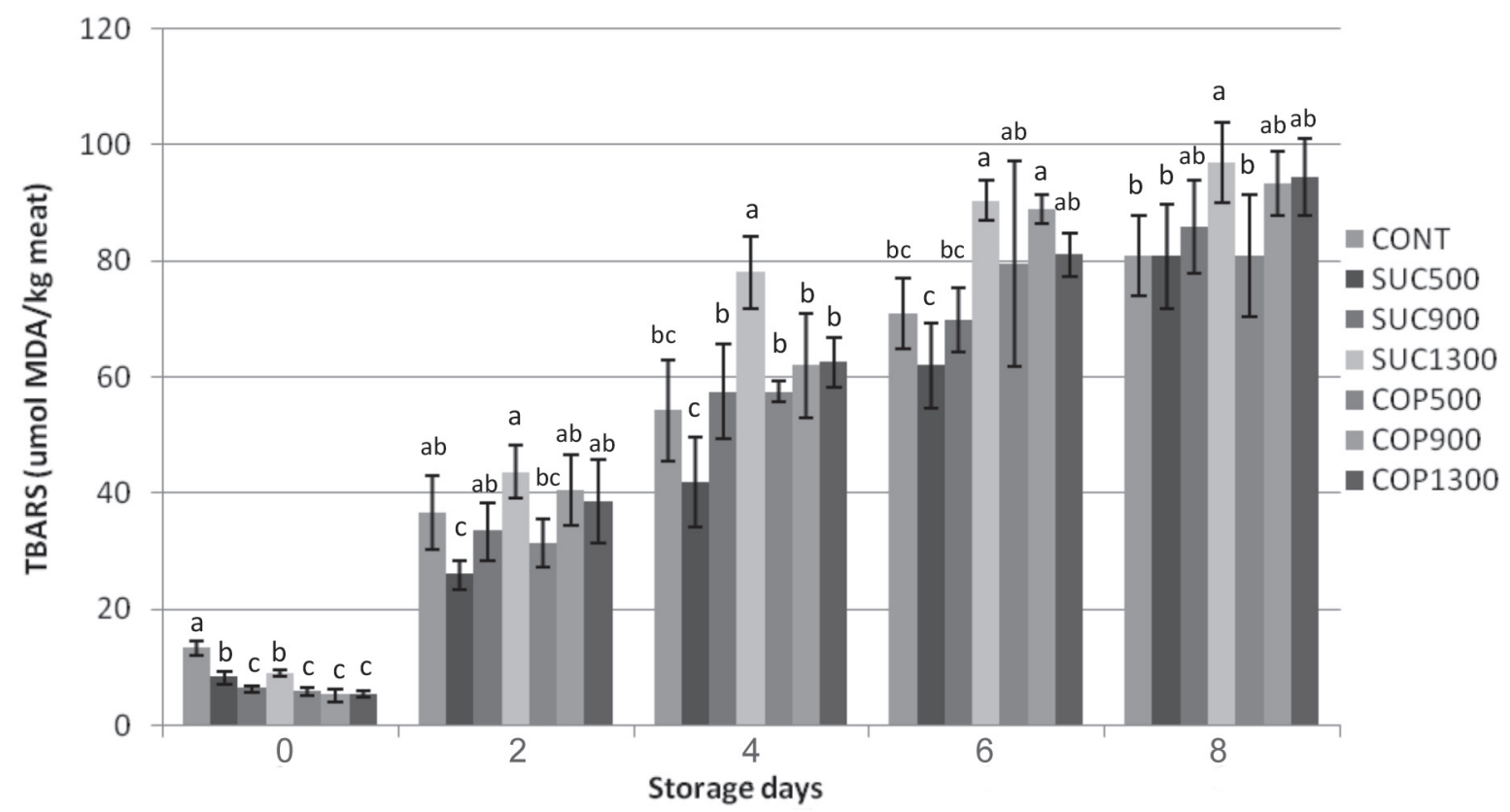

Figure 1 - Secondary compounds of lipid peroxidation (TBARS, $\mu$ mol MDA/kg meat) in precooked breast meatballs during chilled storage (0, 2, 4, 6 e 8 days). * Negative control without antioxidants (CONT) or supplementation of 500, 900 and 1300 ppm of sucupira (SUC) or copaiba (COP) oil resin.a,b, Means with different letters in the same day are statistically different $(p<0.1)$. 
Lima CB de, Racanicci AMC, Oliveira GR, Migotto DL, Amador SA, Souza TC de, Tanure CBGS, Vieira A

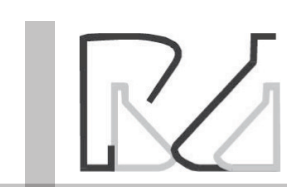

promoted significantly lower $(p<0.1)$ TBARS values when compared with the CONT. However, meat MDA concentration increased as the dietary levels of both oil resins increased. These results indicate that the supplementation with the lowest dosages of SUC and COP may be effective for the prevention of lipid peroxidation in thigh meat.

Smet et al. (2008) evaluated the effect of the dietary supplementation of different concentrations of green tea $(100$ and $200 \mathrm{mg} / \mathrm{kg})$ on the quality of raw chicken breast meat patties stored under refrigeration at $4^{\circ} \mathrm{C}$ for 10 days. The authors verified a significant prooxidant effect $(p<0.05)$ with the inclusion of the high dose $(200 \mathrm{mg} / \mathrm{kg})$ of green tea extract when compared with the low dose.

Previous studies indicated SUC and COP oil resins present in-vitro and in-vivo antioxidant effect due to the composition of these extracts, with high concentrations of phenolic compounds, especially sesquiterpene compounds, such as B-caryophyllene (Romero, 2007; Desmarchelier et al., 2000; Dutra et al., 2009; Maciel, 2002). It is well established that the antioxidant capacity of phenolic compounds is related to their molecular structure (Fukumoto \& Mazza, 2000). In addition, the antioxidant efficacy of these compounds increases with the number of hydroxyl groups. However, the study of Brazilian plants as sources of natural antioxidants is a relatively new topic, and therefore, information relative to their phenolic
Effects of the Dietary Supplementation of Sucupira (Pterodon Emarginatus Vog.) and Copaiba (Copaifera Langsdorffii) Resinoils on Chicken Breast and Thigh Meat Quality and Oxidative Stability

composition and to the in-vitro and in-vivo antioxidant activity of SUC and COP oil resins is very limited. Therefore, further studies are needed to determine sucupira and copaiba oil resin inclusion levels in broiler diets and their influence on meat sensorial properties.

\section{CONCLUSION}

The dietary supplementation of broilers with sucupira oil resin did not improve meat physical quality; however, the addition of copaiba oil resin to the diet resulted in lighter thigh meat and lower cooking weight loss of breast meat, suggesting it effectively retains water inside muscle fibers, possibly improving meat texture and enhancing meat tenderness.

The addition of sucupira oil resin did not promote antioxidant protection of precooked breast meat during storage. However, the addition of $500 \mathrm{mg}$ of sucupira and copaiba oil resins reduced the lipid peroxidation of precooked thigh meat, suggesting antioxidant activity.

\section{ACKNOWLEDGMENTS}

The authors express their gratitude to the Produção Animal Sustentável Network (PAS), a multidisciplinary network connected to the Pró-Centro Oeste Program (CNPq), for providing oil resins and chicken meat, and the grants provided by CNPq/CAPES and Decanato de Pesquisa e Pós-Graduação of the University of Brasilia (DPP/UnB).

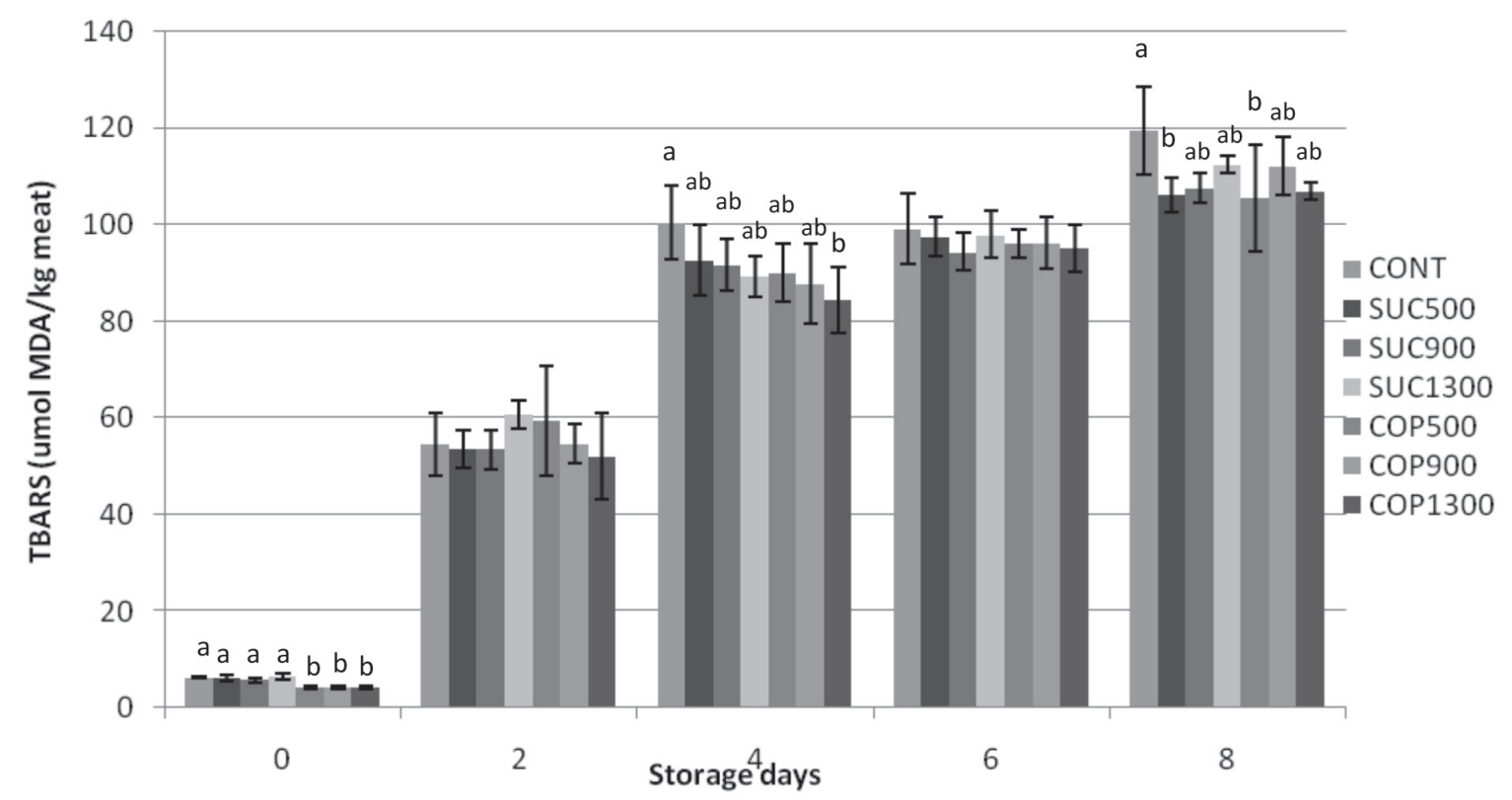

Figure 2 - Secondary compounds of lipid peroxidation (TBARS, $\mu$ mol MDA/kg meat) in precooked thigh meatballs during chilled storage (0, 2, 4, 6 e 8 days). * Negative control without antioxidants (CONT) or supplementation of 500, 900 and 1300 ppm of sucupira (SUC) or copaiba (COP) oil resin. a,b,c Means with different letters in the same day are statistically different $(p<0.1)$. 
Lima CB de, Racanicci AMC, Oliveira GR, Tanure CBGS, Vieira A Migotto DL, Amador SA, Souza TC de,

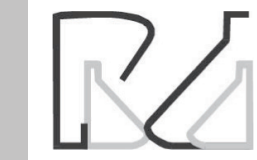

\section{REFERENCES}

Aaslang MD, Bejerholm C, Ertbjerg P, Bertram HC, Andersen HJ. Cooking loss and juiciness of pork in relation to raw meat quality and cooking procedure. Food Quality and Preference 2003;14:277-288.

Almeida ICL, Mendes AA, Oliveira EG, Garcia RG, Garcia EA. Efeito de dois níveis de lisina e do sexo sobre o rendimento e qualidade da carne de peito de frangos de corte. Revista Brasileira de Zootecnia 2002;31:1744-1752

Anand SP, Sati N. Artificial preservatives and their harmful effects: looking toward nature for safer alternatives. International Journal of Pharmaceutical Sciences and Research 2013:4:2496-2501.

Araújo JA, Silva JHV, Amâncio ALL, Lima MR, Lima CB. Uso de aditivos na alimentação de aves. Acta Veterinaria Brasílica 2007;1(3):69-77.

AOAC - Association of Official Analytical Chemists. Official methods of analysis. 15th ed. Arlington: AOAC International; 1990.

AOAC - Association of Official Analytical Chemists. Official methods of analysis. 16th ed. Arlington: AOAC International; 1995. 1025p.

Barbut S, Zhang L, Marcone M. Effects of pale, normal and dark chicken breast meat on microstructure, extractable proteins, and cooking of marinated filets. Poultry Science 2005;84:797-802.

Bouton PE, Harris PV, Shorthose WR. Effect of ultimate $\mathrm{pH}$ upon the waterholding capacity and tenderness of mutton. Journal of Food Science 1971;36:435-439.

Brasil. Ministério da Agricultura e do Abastecimento. Secretaria de Defesa Agropecuária. . Instrução Normativa $\mathrm{N}^{\circ}$ de 17 de Janeiro de 2000. Regulamento técnico de métodos de insensibilização para o abate humanitário de animais de açougue. Brasília, DF; 2000.

Cardenas E, Davies KJ. Mitochondrial free radical generation, oxidative stress, and aging. Journal of Free Radicals in Biology \& Medicine 2000;29:222-230.

Castro JBJ, Castillo CJC, Ortega EMM, Pedreira MS. Jejum alimentar na qualidade da carne de frangos de corte criados em sistema convencional. Ciência Rural 2008;38:470-476.

Cheng Q, Sun D. W. Factors affecting the water holding capacity of red meat products: a review of recent research advances. Critical Reviews in Food Science and Nutrition 2008;48:137-159.

Cortinas L, Villaverde C, Galobart J, Baucells MD, Codony R, Barroeta AC. Fatty acid content in chicken thigh and breast as affected by dietary polyunsaturation level. Poultry Science 2004;83:1155-1164.

Desmarchelier C, Ciccia G, Coussio J. Recent advances in the search for antioxidant activity in South American plants. Studies in Natural Products Chemistry 2000;22:343-367.

Dutra RC, Fava MB, Alves CC, Ferreira AP, Raposo NRB. Antiulcerogenic and anti-inflammatory activities of the essencial oil from Pteridon emarginatus seeds. Journal of Pharmacy and Pharmacology 2009;61:243-250.

Dutra RC, Leite MN, Barbosa NR. Quantification of Phenolic Constituents and Antioxidant Activity of Pterodon emarginatus Vogel Seeds. International Journal of Molecular Science 2008;9:606-614

EU - European Union. Scientific opinion on the re-evaluation of butylated hydroxytoluene BHT (E321) as a food additive. EFSA Journal 2012;10:143.

Froning GW, Uijttenboogaar TG. Effect of post mortem electrical stimulation on colour, texture, $\mathrm{pH}$ and cooking loses of hot and cold deboned chicken broiler breast meat. Poultry Science 1988;67:1535-1544.
Effects of the Dietary Supplementation of Sucupira

(Pterodon Emarginatus Vog.) and Copaiba (Copaifera Langsdorffii) Resinoils on Chicken Breast and Thigh Meat Quality and Oxidative Stability

Fukumoto LR, Mazza G. Assessing antioxidant and prooxidant activities of phenolic compounds. Journal of Agriculture and Food Chemistry 2000:48:3597-3604.

Gandemer G. Lipids in muscles and adipose tissues, changes during processing and sensory properties of meat products. Meat Science 2002;62:309-321

Gaytán CN, Shin D, Sams AR, Keeton JT, Miller RK, Smith SB, et al. Dietary lipid source and vitamin E effect on lipid oxidation stability of refrigerated fresh and cooked chicken meat. Poultry Science 2010;89:2726-2734.

Haak L, Haes K, Van Dyck S, De Smet S. Effect of dietary rosemary and $\alpha$-tocopheryl acetate on the oxidative stability of raw and cooked pork following oxidized linseed oil administration. Meat Science 2008:3:239-247.

Herrero-Jáuregui C, Casado MA, Zoghbi MGB, Martins-Da-Silva RC. Chemical variability of copaifera reticulata ducke oleoresin. Chemistry and Biodiversity 2011;8:674-685.

Kanner J. Oxidative processes in meat and meat products: quality implications. Meat Science 1994;36:169-189.

Kim BC, Ryu YC, Cho YJ, Rhee MS. Influence of dietary $\alpha$-Tocopheryl acetate supplementation on cholesterol oxidation in retail packed chicken meat during refrigerated storage. Bioscience Biotechnology Biochemistry 2006;70(4):808-814.

Leonel FR, Oba A, Pelicano ERL, Zeola NMB, Boiago MM, Scatolini AM, et al. Performance, carcass yield, and qualitative characteristics of breast and leg muscles of broilers fed diets supplemented with vitamin $E$ at different ages. Brazilian Journal of Poultry Science 2007:9:91-97.

Liu F, Dai R, Zhu J, Li X. Optimizing color and lipid stability of beef patties with a mixture design incorporating with tea catechins, carnosine, and $\alpha$-tocopherol. Journal of Food Engineering 2010;2:170-177.

Lonergan SM, Deeb N, Fedler CA, Lamont SJ. Breast Meat Quality and Composition in Unique Chicken Populations.Poultry Science 2003;82:1990-1994.

Lynch MP, Faustman C. Effect of aldehyde lipid oxidation products on myoglobin. Journal of Agricultural and Food Chemistry 2000;48:600604

Maciel MAM, Pinto AC, Veiga Jr VF. Plantas medicinais: a necessidade de estudos multidisciplinares. Química Nova 2002;25:429-438.

Madsen HL, Sørensen B, Skibsted LH, Bertelsen G. The antioxidative activity of summer savory (Satureja hortensis $\mathrm{L}$ ) and rosemary (Rosmarinus officinalis L) in dressing stored exposed to light or in darkness. Food Chemmisty 1998;63:173-180.

Melton SL. Methodology for following lipid oxidation in muscle foods. Food Technology 1983;116:105-111

Min B, Ahn DU. Mechanisms of lipid peroxidation in meat and meat products - a review. Food Science and Biothecnology 2005;14:152163

Mirshekar R, Dastar B, Shabanpour B. Effect of Rosemary, Echinacea, green tea extracts and ascorbic acid on broiler meat quality. Pakistan Journal of Biological Sciences 2009;12:1069-1074.

Morrisey PA, Sheehy PJA, Galvin K, Kerry JP, Buckey DJ. Lipid stability in meat and meat products. Meat Science 1998;49:73-86.

Müller AT, Paschoal EC, Santos JMG. Impacto do manejo pré-abate na qualidade da carne de frango. Revista em Agronegócios e Meio Ambiente 2012;5:61-80. 
Lima CB de, Racanicci AMC, Oliveira GR, Migotto DL, Amador SA, Souza TC de, Tanure CBGS, Vieira A
Northcutt JK, Foegeding EA, Eden FW. Water-holding properties of thermally preconditioned chicken breast and leg meat. Poultry Science 1994;73:308-316.

Novello D, Ost PR, Neumann M, Pellegrini LG. Avaliação bromatológica e perfil de ácidos graxos da carne de frangos de corte alimentados com rações contendo farinha de carne e ossos. Ambiência 2008;4:355-366.

NEPA - Núcleo de Estudos e Pesquisas em Alimentação. Tabela brasileira de composição de alimentos. $4^{\text {a }}$ ed. Campinas: Editora UNICAMP; 2011. p. 16-104.

Passoto AJ, Penteado MVC, Mancine-Filho J. Atividade antioxidante do b-caroteno e da vitamina A: estudo comparativo com antioxidante sintético. Revista Ciência e Tecnologia dos Alimentos 1998;18(1):68-72.

Qiao M, FletcherD L, Smith DP, Northcutt JK. The effect of broiler breast meat color on $\mathrm{pH}$, water-holding capacity, and emulsification capacity. Poultry Science 2001;80:676-680.

Racanicci AMC, Danielsen B, Menten JFM, Regitano-D'Arce MAB Skibsted LK. Antioxidant effect of dittany (Origanum dictamnus) in pre-cooked chicken meat balls during chill storage in comparison to rosemary (Rosmarinus officinalis). European Food Research and Technology 2004;218:521-524.

Romero AL. Contribuição ao conhecimento químico do óleo-resina de copaiba: configuração absoluta de terpenos [dissertação]. Campinas (SP): Instituto de Química da Universidade Estadual de Campinas; 2007.

Rostagno HS, Albino LFT, Donzele JL, Gomes PC, Oliveira RF, Lopes DC, et al. Tabelas brasileiras para aves e suínos: composição de alimentos e exigências nutricionais. $3^{a}$ ed. Viçosa: Universidade Federal de Viçosa; 2011.
Effects of the Dietary Supplementation of Sucupira

(Pterodon Emarginatus Vog.) and Copaiba (Copaifera Langsdorffii) Resinoils on Chicken Breast and Thigh

Meat Quality and Oxidative Stability

Shafey TM, Mahmoud AH, Hussein ES, Suliman G. The performance and characteristics of carcass and breast meat of broiler chickens fed diets containing flaxseed meal. Italian Journal of Animal Science 2014;13:752-758

Simitzis PE, Symeon GK, Charismiadou, MA, Ayoutanti AG, Deligeorgis SG. The effects of dietary hesperidin supplementation on broiler performance and chicken meat characteristics. Canadian Journal of Animal Science 2011;91:275-282.

Smet K, Raes K, Huyghebaert G, Haak L, Arnouts S, De Smet S. Lipid and protein oxidation of broiler meat as influenced by dietary natural antioxidant supplementation. Poultry Science 2008;87:1682-1688

Torres EAFS, Campos NC, Duarte M, Garbelotti ML, Philippi ST, Rodrigues RSM. Composição centesimal e valor calórico de alimentos de origem animal. Ciência e Tecnologia de Alimento 2000;20:145-150.

USDA - United States Department of Agriculture. Composition of foods raw, processed, prepared USDA national nutrient database for standard reference. Washington, DC; 2012. p. 106-110.

Wang XQ, Chen X, Tan HZ, Zhang DX, Zhang HJ, Wei S, et al. Nutrient density and slaughter age have differential effects on carcass performance, muscle and meat quality in fast and slow growing broiler genotypes. British Poultry Science 2013;54:50-61.

Young JF, Stagsted J, Jensen SK, Karlsson AH, Henckel P. Ascorbic acid, a-tocopherol and oregano supplements reduce stress-induced deterioration of chicken meat quality. Poultry Science 2003;82:13431351.

Zhang X, Wang G, Zhou Y, Wang T. Effect of RRR- $\alpha$ - tocopherol succinate on the meat quality and antioxidative status in broilers. South African Journal of Animal Science 2012;42:341-353. 
